\title{
A Reflection of Minimum Adequate Education in South Carolina More Than Fifty Years Later
}

\author{
Frederick M. G. Evans, Ed. D. \\ South Carolina State University, Orangeburg, SC, USA
}

\begin{abstract}
The issues and challenges of minimum adequate public school education in the State of South of South Carolina has been a struggle between lawmakers and taxpayers for more than fifty years. The enactment of the Civil Rights Act of 1964 led to forced school integration, busing, and led to whites' physical moving out of selected school districts. Selected public schools filed a lawsuit against the State of South Carolina to the Supreme Court with the claim of failing to provide adequate and equal education to all children in the state. This reflection focuses on the Abbeville case in context, funding issues, and inadequate facilities, which concludes with a reflective view of the Brown v. The Board of Education 1954 decision.
\end{abstract}

Keywords: Abbeville case, Civil Rights act, minimally adequate education, Education Finance Act of 1977

\section{Introduction}

The 1896 Plessey v. Ferguson (separate but equal doctrine) Supreme Court case was overturned by the Brown v. The Board of Education Supreme Court case in the 1954 ruling "separate but equal was unconstitutional.” The Brown's case included the Briggs case and four other cases, stemmed from a 1949 petition by the parents of African American children attending schools in Clarendon County, South Carolina, seeking adequate funding. A few years later, Lyndon Johnson signed the Civil Rights Act of 1964. The State of South Carolina struggled with the Civil Rights Act of 1964, as did many southern states. The federal legislation led to integration, forced integration, busing, and "white flight.” Opposition quickly led to demonstrations and violence among blacks and whites. The State of South Carolina is located on the eastern seaboard of the Atlantic coast in North America with an ethnic profile of approximately 29.80\% Black, 69.10\% White, and $2.60 \%$ other. The student ethnicity profile consists of $42 \%$ Black, $54.80 \%$ White, and $3.10 \%$ other (South Carolina Education Profiles, 2001). While the ethnic profile data are derived from 2001 for the purpose of this personal reflection, the percentages may vary slightly $+/-0.9 \%$ in 2017.

The "footprints" and evidence of the slave trade are still visible in Beaufort, SC and Charleston, SC. The old slave market in Charleston, SC is open to the public, as well as, the Penn Center in Beaufort, SC. The relevance of the "footprints" is parallel to Interstate 95 (known as the Corridor of shame) with respect to public schools that are still operating in the same areas that have not received equal funding from the State of South Carolina. This reflection of the Civil Rights Act and adequate education in the State of South Carolina is addressed with a specific focus on "the parallel of little change fifty years later and many variables in the

Frederick M. G. Evans, Ed. D., Dean, College of Graduate \& Professional Studies; Chair, Department of Educational Leadership, South Carolina State University. 
Abbeville Supreme Court case.”

\section{Abbeville Court Case in Context}

In 2004, the State of South Carolina still failed to provide adequate and equal education to all children in the state. As a direct result, thirty-six (36) school districts filed a lawsuit against the State of South Carolina, which became known as the Abbeville case. Eight (8) of the thirty-six (36) school districts were identified as plaintiffs during the trail. The trail was held in the Clarendon County Courthouse, which is the same county of the Briggs case. The site of the trail was only forty-five minutes away from many colleges and universities and approximately one hour away from the State Capitol of South Carolina.

The Abbeville case focused primarily on "minimally adequate education," which the Supreme Court outlined as (1) the ability to read, write, and speak the English language, and knowledge of mathematics and physical science; (2) a fundamental knowledge of economic, social, and political systems, and of history and governmental processes; and (3) academic and vocational skills. However, the Court had to determine whether the State of South Carolina was offering educational opportunities to children in the plaintiff districts. The Court then examined both State inputs and student outcomes. The "inputs" were defined as an educational opportunity. The "outcomes" were measured as student achievement. The plaintiffs augured that the State failed to fund their school districts equally to ensure adequate education. The state augured that the children in the Plaintiff districts choose not to learn and $40 \%$ of the students in the plaintiff's district are minimally qualified to advance to the next grade level proves that opportunity exists for all. The State further augured that $60 \%$ of 9-13 years old children refuse to learn. Many of the same schools were considered failing schools in 2014. In this regard, the debate continues and financial issues must be addressed.

\section{Funding Issues}

All of the available, accessible research data revealed the fact that schools in the Plaintiff districts have low financial resources and high student needs. The said school districts have low fiscal capacity to include low per capita incomes and low tax bases, as well as, higher minority populations than the State averages. The demographics are in concert with very high percentages of impoverished, disadvantaged students, and unsatisfactory achievement levels across all performance measures. Regardless of the geographical considerations, the State of South Carolina is mandated through the Education Finance Act of 1977 (EFA)

To guarantee to each student in the public schools of South Carolina the availability of at least minimum education programs and services appropriate to his needs, and which are substantially equal to those available to other students with similar needs and reasonably comparable from a program standpoint to those students with similar needs and reasonably comparable from a program standpoint to those students of all classifications, notwithstanding geographical differences and varying local economic factors. (Education Finance Act of 1977, 59-20-10, et seq.)

Just one example of this flawed Act (EFA) required the State to pay all school transportation cost, but school districts pay approximately sixty percent of the cost. To this regard, the base student cost of the EFA has been fully funded for only eight years of the twenty-six years since its passage. The poorer school districts must redirect funding to cover such expenses thus shifting costs from possible instructional services to support transportation. These practices are still being implemented in 2017 as school districts continue to struggle with inadequate funding issues. In other words, when EFA funds are cut, the budget reductions disproportionately affect poorer districts because of this dependence on EFA funds. The State of South Carolina funded 70.9\% of 
education in 1960, 41.89\% in 2002, and the percentage continues to decrease year after year. The State of South Carolina, contrary to other states, has required districts to assume more of the cost of education over time.

The school districts represented in the Abbeville case lacked funds to meet their students' remedial and compensatory programs. No local or state money was available for after-hour programs or summer school leading to reliance on federal grants in order to serve a portion of the students who needed such programs. This practice received limited funding to implement targeted programs as a "stop gap measure" and to adhere to the mandates, temporarily. The augments today still reflect the assumption that South Carolina has never attempted to determine what it costs to educate children and fund adequate facilities in South Carolina, including the children in the Abbeville districts (I 95 corridor).

\section{Inadequate Facilities}

The school facilities in the school districts represented in the Abbeville case showed through studies distressingly high facilities’ deficiencies with an estimated cost of approximately over four billion dollars for capital needs improvements. It is so unfortunate that the same issues remain fifty years later facing the same disparities. The relationship between facilities and student performance is an expected understanding. The South Carolina Education Oversight Committee (EOC) reported in its 2001 Report to the South Carolina General Assembly the following:

One out of every five schools in this state is rated by the principal as having a direct negative impact on school productivity. Among facilities factors adversely affecting the educational process are overcrowding, poor physical condition of the structure, portables, lack of storage, inadequate laboratory space. Because (1) this study affirms previous research indicating that school facilities affect student outcomes; (2) one of every five schools in this state is rated as making a negative impact on the educational process; and (3) the average school facilities is 70\% through its expected life cycle, it is recommended that a comprehensive and adequate system of funding school construction in South Carolina be developed and implemented. (EOC, 2001)

Citizens within and out of the school districts represented in the Abbeville case verbalized their opinions through local media stating, "the State is not providing adequate facilities to students in South Carolina." The referenced South Carolina Education Oversight Committee Report to the South Carolina General Assembly in 2001 is extremely important because very little change has occurred regarding special allocated funding for new school facilities equipped with modern technology, top rated teachers, and after school remedial programs supported with bus transportation to ensure that children are able to participate in such.

\section{Conclusion}

The Legislature in the State of South Carolina does a good job of enacting laws intended to promote education, but does a poor job of supporting the laws financially, respectfully. Fifty years later, some school districts in South Carolina still lack qualified teachers, instructional materials, usable technology, effective leaders, labs, bus transportation to support after school programs, compensatory and remedial programs, professional development for all teachers, and sufficient library and media centers. Other concerns and issues that rests on the "backdrop" of the Civil Rights Act through this academic reflection include but are not limited to (1) recruiting and retaining effective teachers for every classroom; (2) need for services for all students to reach high expectations and performance criteria; (3) services for disable, migrant, low-performing students; (4) instructional needs to reflect equal and adequate education; (5) resources to meet federal requirements; (7) lack 
of funds for construction and maintenance of school facilities. The above observations directly contribute to the academic achievement gap in many school districts in the State of South Carolina.

Many school districts have "self-segregated by personal income bracket" through real estate developments; thus, establishing higher tax brackets for school zones. Education in the State of South Carolina is adequate in some school districts but not in others. Other self-segregated measures include, but not limited to, charter schools and home schooling. Parents that can financially afford to daily transport their children to charter and private schools are academically removed, but still are taxed for the basic financial support of public education. The Landmark Abbeville case is still pending in 2017 and as a result is becoming parallel with the Brown v. The Board of Education decision, which many believe that justice, has been denied to many generations of predominantly black and impoverished children and the effects are still being felt more than fifty years later.

\section{References}

Education Finance Act of 1977, 59-20-10, et seq.

South Carolina Education Oversight Committee. (2001, March 1). The South Carolina General Assembly Report. 